\title{
Het doel heiligt het middel? Over de noodzaak van uniforme criteria voor evaluatie van de effectiviteit en efficiëntie van de opsporing*
}

Dave van Toor

\section{Inleiding}

De bewaarplicht van telecommunicatiegegevens heeft het afgelopen jaar zowel op Europees als nationaal niveau met tegenslag te maken gekregen. Het Hof van Justitie van de Europese Unie (hierna: het Europese Hof) oordeelde in april 2014 dat de Europese Dataretentierichtlijn (2006/24) in strijd is met de artikelen 7 en 8 van het Handvest van de grondrechten van de EU. ${ }^{1}$ Het Europese Hof richtte zich daarbij vooral op de vraag of het noodzakelijk is om alle informatie van elk telecommunicatieapparaat van alle Europese burgers voor ten minste zes maanden te bewaren, zoals de richtlijn bepaalt. ${ }^{2}$ De ongedifferentieerde dataretentie leidde eerder ook bij het Europese Hof voor de Rechten van de Mens (EHRM) tot de constatering van een schending van het recht op respect voor het privéleven. ${ }^{3} \mathrm{De}$ Rechtbank Den Haag volgde dit oordeel in maart van dit jaar door de Wet bewaarplicht telecommunicatiegegevens buiten werking te stellen. ${ }^{4}$ Voor de opsporingspraktijk heeft dit grote consequenties, omdat politie en justitie zich in (nog) steeds toenemende mate toeleggen op het verzamelen en analyseren van per-

* Dave van Toor LLM Bsc is onderzoeksmedewerker aan de Universität Bielefeld en buitenpromovendus aan de Radboud Universiteit Nijmegen.

1 HvJ EG 8 april 2014, zaken C-293/12 \& C-594/12, ECLI:EU:C:2014:238.

2 ' 56 As for the question of whether the interference caused by Directive 2006/24 is limited to what is strictly necessary, it should be observed that, in accordance with Article 3 read in conjunction with Article 5(1) of that directive, the directive requires the retention of all traffic data concerning fixed telephony, mobile telephony, Internet access, Internet e-mail and Internet telephony. It therefore applies to all means of electronic communication, the use of which is very widespread and of growing importance in people's everyday lives. Furthermore, in accordance with Article 3 of Directive 2006/24, the directive covers all subscribers and registered users. It therefore entails an interference with the fundamental rights of practically the entire European population.

57 In this respect, it must be noted, first, that Directive 2006/24 covers, in a generalised manner, all persons and all means of electronic communication as well as all traffic data without any differentiation, limitation or exception being made in the light of the objective of fighting against serious crime.'

3 EHRM (GC) 4 december 2008, 30562/04 \& 30566/04, NJCM-Bulletin 2009, 4 (m.nt. Van der Staak), par. 125 (S. \& Marper/het Verenigd Koninkrijk).

4 Rb. Den Haag 11 maart 2015, ECLI:NL:RBDHA:2015:2498. 
soonsgegevens. ${ }^{5}$ Politie en het Openbaar Ministerie (OM) zijn daarom aan een 'tegenoffensief' begonnen. Onlangs verscheen van hun hand het rapport $D e$ bewaarplicht telecomgegevens en de opsporing: Het belang van historische telecommunicatiegegevens voor de opsporing. ${ }^{6}$ Volgens plaatsvervangend korpschef Bik en procureur-generaal Van der Burg is het rapport geschreven en gepubliceerd om 'belangstellenden meer inzicht te geven in het belang van dergelijke gegevens en de bewaarplicht daarvan, bij de aanpak van ernstige criminaliteit'. ${ }^{7}$ De vraag is echter of dit tegenoffensief wel het gewenste effect sorteert. Maakt het rapport duidelijk wat precies het belang van de bewaarplicht van historische telecommunicatiegegevens voor de opsporingspraktijk is?

In deze bijdrage zet ik uiteen dat het rapport eerder aanvullende argumenten geeft om de bewaarplicht buiten werking te stellen of anders ten minste gedegen nader onderzoek te doen naar de effectiviteit en efficiëntie van de bewaarplicht en de analyse en het gebruik van telecommunicatiegegevens in het strafprocesrecht. Ten behoeve daarvan behandel ik achtereenvolgens hoe de wetgever 'het belang' van een opsporingsmethode analyseert. Daarna volgt een beschrijving van het belang van de bewaarplicht voor de strafvordering, zoals opgesteld door politie en het OM. Ten slotte concludeer ik dat weinig onderzoek wordt gedaan (of tenminste weinig onderzoeksresultaten openbaar worden gemaakt) naar het belang van een specifieke onderzoeksmethode voor de strafvordering en welke mogelijke problemen dat voor de praktijk oplevert.

\section{Analyse van de effectiviteit en efficiëntie van opsporingsmethoden door de wetgever}

De razendsnelle technologische en wetenschappelijke ontwikkelingen op het gebied van telecommunicatie en andere elektronische apparaten, en de verschillende mogelijkheden om lichaamsmateriaal te analyseren (profiel- en verwantschapsanalyse, opstellen uiterlijke kenmerken) stellen de wetgever en opsporingsautoriteiten voor de keuze om nieuwe bevoegdheden te creëren en te gebruiken. Maar wanneer en waarom moet een nieuwe onderzoeksmethode ten behoeve van de opsporing van strafbare feiten beschikbaar worden gemaakt voor politie en justitie? Als met een nieuwe methode bijvoorbeeld sneller, betrouwbaarder en/of

5 M.G.J.M. van der Staak, 'De individuele, relationele en maatschappelijke waarde van privacy', Strafblad 2014, 4, p. 278; J.B.J. van der Leij, 'De staat van onze informationele privacy binnen het domein van opsporing, vervolging en berechting van strafbare feiten', Strafblad 2014, 4, p. 271. Vgl. J.H. Moor, 'Towards a theory of privacy in the information age', Computers and Society 1997, 1, p. 27-32; H. Nissenbaum, 'Protecting privacy in an information age: the problem of privacy in public', Law and Philosophy 1998, 5-6, p. 559-596, waarin de huidige tijdgeest (in het strafprocesrecht) de 'information age' wordt genoemd.

6 W.N. Ferdinandusse, D. Laheij \& J.C. Hendriks, De bewaarplicht telecomgegevens en de opsporing. Het belang van historische telecommunicatie gegevens voor de opsporing, Den Haag: Politie en Openbaar Ministerie 2015.

7 R. Bik \& G.W. van der Burg, 'Woord vooraf', in: W.N. Ferdinandusse, D. Laheij \& J.C. Hendriks, De bewaarplicht telecomgegevens en de opsporing. Het belang van historische telecommunicatie gegevens voor de opsporing, Den Haag: Politie en Openbaar Ministerie 2015, p. 3. 
goedkoper hetzelfde bewijsmateriaal kan worden vergaard, zal de bevoegdheid in de praktijk hoogstwaarschijnlijk worden gebruikt. Met andere woorden, nieuwe methoden moeten op bepaalde kenmerken, waaronder de efficiëntie, worden beoordeeld, zodat de toevoegde waarde duidelijk wordt. ${ }^{8}$ Aangezien de wetgever telkens nieuwe bevoegdheden creëert, is het mogelijk dat hij door de jaren heen een duidelijk en vast toetsingskader heeft ontwikkeld. In memories van toelichting, wetsevaluaties en parlementaire overleggen komt naar voren waaraan opsporingsbevoegdheden door de wetgever en onderzoekers worden getoetst, maar zelden wordt systematisch en gestructureerd een toetsingskader toegepast. Ook de wet bevat geen handvatten voor dit onderwerp. ${ }^{9}$ De analyse van de toegevoegde waarde van opsporingsmethoden voor de waarheidsvinding vindt meestal niet op eenzelfde manier en aan de hand van gelijkluidende criteria plaats. Ik geef een aantal voorbeelden.

De bevoegdheden die zijn opgenomen in de Wet maatregelen bestrijding voetbalvandalisme en ernstige overlast worden geëvalueerd op de punten wettelijke voorwaarden, subsidiariteit en effecten van de maatregel. ${ }^{10}$ Met het eerste criterium wordt bedoeld of de wet van toepassing is op de gevallen waarvoor de wet is bedoeld. Het betreft dan de kwestie of de wettelijke voorwaarden - waaronder herhaaldelijke en ernstige vrees voor herhaling van vandalisme of overlast - te beperkend zijn, zodat de wet niet op de juiste gevallen wordt toegepast. Hiermee wordt in mijn ogen bedoeld en beoordeeld of de wet effectief is. Het subsidiariteitsbeginsel houdt in of met minder ingrijpende maatregelen dan op grond van de onderhavige wet hetzelfde resultaat kan worden behaald. En de variabele 'effecten van de maatregel' gaat over het doel van de wet: zorgt de opgelegde maatregel daadwerkelijk voor minder overlast?

Op een geheel andere wijze wordt onder andere het automatic number plate recognition-systeem (ANPR) beoordeeld tijdens het overleg van de vaste commissie voor Veiligheid en Justitie. De afweging wordt voornamelijk gemaakt tussen de belangen van de opsporing en het belang van het beschermen van de privacy. ${ }^{11} \mathrm{De}$ belangen van de opsporing worden verder uitgewerkt met onder andere de kosten van de bevoegdheid - een sluitend camerasysteem, de manuren die noodzakelijk

Vgl. M.A.H. van der Woude, 'Evaluatie antiterrorismewetgeving', Openbaar Bestuur 2011, 5, p. 9. Van der Woude overweegt dat de toegevoegde waarde van antiterrorisme maatregelen regelmatig ter discussie is gesteld.

9 Overigens zou een instrumenteel toetsingskader in de wet niet misstaan. De wet geeft geen limitatieve opsomming van opsporingsmethoden en kan dat, gezien de constante technologische en wetenschappelijke voortuitgang, ook niet geven. Hierdoor worden in de praktijk regelmatig methoden ten behoeve van de opsporing ingezet zonder expliciete wettelijke grondslag. Dit houdt in dat ook de normering van de methode niet wettelijk is verankerd. Het opnemen van algemene toetsingscriteria, zowel instrumenteel als rechtsbeschermend, kan dit hiaat vullen. Vgl. G. Knigge \& N.J.M. Kwakman, 'Het opsporingsbegrip en normering van de opsporingstaak', in: M.S. Groenhuijsen \& G. Knigge (red.), Het vooronderzoek in strafzaken, Deventer: Kluwer 2001, p. 344.

10 H. Winter e.a., Op doel?, Groningen: Rijksuniversiteit Groningen/Pro facto 2012, p. 62.

11 Kamerstukken II 2012/13, 31051, 12, p. 2-3. 
zijn om de beelden te bekijken -, de betrouwbaarheid van de techniek en het effect van de methode op de hoeveelheid criminaliteit. ${ }^{12}$

Twee andere voorbeelden uit de parlementaire geschiedenis - de aanvulling van het Wetboek van Strafvordering met voorzieningen ten behoeve van DNA-onderzoek in strafzaken (Wet DNA I) ${ }^{13}$ en de Wet DNA-onderzoek bij veroordeelden ${ }^{14}$ - laten hetzelfde beeld zien: geen systematische analyses van de bevoegdheden op bepaalde kenmerken. In de memorie van toelichting bij de Wet DNA I komen veel opmerkingen over instrumentele en rechtsbeschermende toetsingspunten naar voren. De belangrijkste overweging om DNA-onderzoek mogelijk te maken in de strafrechtspleging is 'omdat dit onderzoek van grote betekenis kan zijn voor de opheldering van doorgaans moeilijk te bewijzen zeden- en geweldsdelicten'. ${ }^{15}$ Ook in de memorie van toelichting bij de Wet DNA-onderzoek bij veroordeelden ligt de nadruk op effectiviteit. ${ }^{16}$ Omdat de overheid over het DNA-profiel van de veroordeelde beschikt, kunnen nog niet opgehelderde delicten en nog te plegen strafbare feiten eenvoudig(er) worden opgespoord.

Als laatste voorbeeld een op verzoek van het ministerie van Veiligheid en Justitie verricht evaluatieonderzoek. In het onderzoek naar de DNA-databank worden twee heel duidelijke vragen gesteld die volgens de onderzoekers moeten worden beantwoord voordat extra financiële investering voor een opsporingsbevoegdheid is gerechtvaardigd: 'A. In welke mate draagt de toepassing van de Wet DNA-V bij aan de opsporing, vervolging en berechting van strafbare feiten (effectiviteit)? B. Hoe verloopt op dit moment de uitvoering van de Wet DNA-V binnen de Nederlandse strafrechtsketen (efficiëntie)?'17 De vraag naar de effectiviteit van een middel bevat het onderzoek naar de bijdrage die bevoegdheid levert aan het halen van de doelen van de strafrechtspleging. De efficiëntie van een middel is meer een vraag van economische aard: 'Bereiken we het resultaat zo voordelig mogelijk? (...) en krijgen we het beste resultaat voor de investering?'18 De effectiviteit en efficiëntie worden vervolgens beoordeeld aan de hand van een model uit de organisatiekunde waarbij de input, throughput, output, outcome en impact van de methode centraal staan (hierover later meer).

Ondanks de grote verscheidenheid aan gebruikte terminologie en toetsen, trek ik naar aanleiding van de beschreven voorbeelden twee tussenconclusies. De eerste conclusie is dat er veel verschillende bewoordingen en geen vast toetsingskader voor de beoordeling van opsporingsmethoden worden gebruikt, maar dat er wel een tweetal algemene punten uit de afwegingen kan worden gedistilleerd die worden gebruikt om de bijdrage van een opsporingsmethode aan de waarheidsvinding te beoordelen. Op verschillende manieren komen de volgende twee beoorde- 
lingspunten regelmatig terug: (1) de effectiviteit ${ }^{19}$ van de methode, en (2) de efficiëntie ${ }^{20}$ van de methode.

De tweede conclusie betreft de uitwerking van de twee aandachtspunten. Zoals hiervoor al werd opgemerkt, vinden de analyses van nieuwe opsporingsmethoden meestal niet op eenzelfde manier en met uniforme criteria plaats. Effectiviteit en efficiëntie zijn geen eenduidige begrippen en bestaan uit meerdere onderdelen, derhalve komen de analyses van de wetgever willekeurig over. Er bestaat mijns inziens geen volledig toetsingskader waarmee de wetgever nieuwe opsporingsmethoden beoordeelt. Hierdoor kunnen bestaande en nieuwe methoden moeilijk met elkaar worden vergeleken. Dit terwijl de wetgever zelf 'de formulering van nauwkeurige doelstellingen', 'de noodzaak van overheidsinterventies' en 'alternatieven voor bereiken van het doel' als kenmerken van het regelgevingsproces benoemt. ${ }^{21}$ Niet alleen op het niveau van wetgeving kunnen vragen worden gesteld over de evaluatie van opsporingsmethoden. Ook rijst, door het ontbreken van duidelijke toetsing over de effectiviteit en efficiëntie van een opsporingsmethode, de vraag hoe en welke argumenten de strafvorderlijke autoriteiten besluiten om de ene methode in een concrete zaak wel en de andere methode niet in te zetten.

\section{De effectiviteit en efficiëntie van de bewaarplicht telecomgegevens}

Het rapport De bewaarplicht telecomgegevens en de opsporing lijdt aan hetzelfde probleem. Dus ook voor politie en OM, de instanties die de opsporingsmethoden gebruiken, is het (blijkbaar) onmogelijk om systematisch en gestructureerd het belang van een opsporingsmethode te beoordelen. Politie en OM maken de beantwoording van de vraag naar het succes van de methode van het bewaren en vervolgens analyseren van historische telecommunicatiegegevens afhankelijk van de vraag voor wie en wanneer het opvragen en gebruiken van telecommunicatiegegevens succesvol is. ${ }^{22}$ Twee zeer relevante vragen. Is een methode succesvol, dat wil zeggen effectief, als daarmee bewijs wordt geproduceerd dat als startinformatie kan worden gebruikt door de politie? Of enkel als de rechter de verkregen resultaten voor het bewijs gebruikt? Zo zijn al twee verschillende autoriteiten (politie en rechter) en twee onderscheidende gevolgen (startinformatie en bewijs) te diffe-

19 In het evaluatieonderzoek naar de Wet maatregelen bestrijding voetbalvandalisme en ernstige overlast betreffen de variabelen de wettelijke voorwaarden en effecten van de maatregel de vraag naar de effectiviteit. Andere bewoordingen die in parlementaire stukken worden gebruikt om de effectiviteit van een methode aan te duiden zijn onder andere de opheldering van strafbare feiten, de betrouwbaarheid van de techniek en het effect op de hoeveelheid criminaliteit.

20 In het evaluatieonderzoek naar de Wet maatregelen bestrijding voetbalvandalisme en ernstige overlast betreft de variabele subsidiariteit de vraag naar de efficiëntie. Een andere bewoording die in parlementaire stukken te vinden is die de efficiëntie van een methode betreft, is de kosten van de methode.

21 Aanwijzingen voor de regelgeving, circulaire van de minister-president, Stcrt. 2005, 87, direct te raadplegen via http://wetten.overheid.nl/BWBR0005730/Opschrift/geldigheidsdatum_01-02 -2015, laatst geraadpleegd op 9 juni 2015.

22 Ferdinandusse e.a. 2015, p. 32-34. 
rentiëren. Overigens wijken deze vragen ter beoordeling van het belang van de bewaarplicht (natuurlijk) af van de toetsing van opsporingsmethoden in de hiervoor geschetste voorbeelden.

Om verschillende redenen kunnen de vragen in het rapport echter niet worden beantwoord volgens de onderzoekers: 'Voor politie en OM [is het] niet mogelijk om in cijfers aan te geven in hoeveel zaken het opvragen van historische telecomgegevens "succesvol" is geweest voor de opsporing. ${ }^{23}$ Met andere woorden: de vragen of, voor wie en waarom de bewaarplicht effectief is, zijn derhalve niet te beantwoorden. Dit komt volgens de auteurs mede doordat veel vonnissen niet worden gepubliceerd en doordat opsporingsmethoden altijd in onderlinge samenhang worden gebruikt, waardoor de zelfstandige bijdrage van elke methode achteraf niet te bepalen is. Dit zijn inderdaad lastige obstakels om de effectiviteit van een enkele methode te onderzoeken, maar de gestelde vragen kunnen daarnaast zeker niet worden beantwoord omdat de auteurs zelf niet beargumenteren voor wie (politie en/of rechter) en wanneer (gebruikt als startinformatie/schakelbewijs/ bewijs) een methode als opsporingsmiddel succesvol is of moet zijn. Daarbij wordt de efficiëntie van het opslaan, opvragen, analyseren en gebruiken van telecommunicatiegegevens nog volledig over het hoofd gezien. Overigens wordt in het rapport de conclusie dat het belang van opsporingsmiddelen niet met statistieken kan worden onderbouwd, direct veralgemeniseerd: 'Om dezelfde reden kan overigens van geen enkel opsporingsmiddel met statistieken de noodzaak worden onderbouwd: ook niet van telefoontaps, doorzoekingen, getuigenverhoren, observaties, etc.' 24

Dat het rapport vervolgens eindigt met de conclusie dat het opslaan van historische telecommunicatiegegevens 'van essentieel belang is' voor de opsporing, ${ }^{25}$ is op zijn minst verwonderlijk. De door de politie en het OM zelf geformuleerde vragen worden niet in voldoende en bevredigende mate beantwoord. Waar in het rapport ten minste een poging wordt gedaan om het belang van de bewaarplicht te benadrukken - namelijk door veel en ernstige zaken op te sommen waarin historische telecommunicatiegegevens op enig moment een rol van betekenis voor iemand hebben gespeeld -, ontbreekt echter de nuancering. Zo wordt voor het contrast slechts een aantal zaken genoemd waarin de methode ontlastend bewijs produceerde en wordt geen melding gemaakt van de hoeveelheid zaken en manuren die zijn besteed aan het analyseren van de gegevens zonder dat het een rol van betekenis in de strafzaak speelde. Als niet duidelijk is voor wie, op welke wijze en met welke kosten en baten een methode succesvol is voor de opsporing van strafbare feiten, hoe kan de keuze voor een bepaald opsporingsmiddel dan worden gefundeerd? 


\section{Oproep voor meer en beter onderzoek naar evaluatie van de effectiviteit en efficiëntie van opsporingsmethoden}

In het vorenstaande werd het evaluatieonderzoek naar een DNA-databank van Taverne en collega's aangehaald. ${ }^{26}$ Dit rapport is een prachtig voorbeeld van hoe het ook kan. ${ }^{27}$ Zeer gestructureerd, met duidelijke onderzoeksvragen en goede operationalisatie van begrippen en hoofdvragen onderwerpen de onderzoekers de DNA-databank aan een grondige analyse om het belang van een dergelijke databank voor de strafvordering te onderbouwen. De begrippen effectiviteit en efficiëntie betreffen de doeltreffendheid en doelmatigheid van een opsporingsmethode. Wordt het doel dat de methode beoogt te bereiken daadwerkelijk bereikt? Zo ja, hoeveel en welke middelen zijn nodig om het doel te bereiken? In deze paragraaf worden elementen besproken waarmee kan worden beoordeeld in welke mate een opsporingsmethode effectief en efficiënt is. Hiervoor wordt voornamelijk geput uit een klassiek model uit de organisatiekunde. ${ }^{28} \mathrm{Om}$ te beoordelen of een proces in een organisatie effectief en efficiënt is, dient te worden bekeken wat de input, throughput, output, outcome (en impact) is. ${ }^{29}$

De efficiëntie van een bevoegdheid hangt af van de hoeveelheid middelen (input), taken, processen en activiteiten die worden uitgevoerd (throughput) en die noodzakelijk zijn om de resultaten van de methode (output) te verkrijgen. Een voorbeeld. Om te beoordelen of een DNA-profiel matcht met de profielen in de database zijn als input personeel (arts en opsporingsambtenaren) en goederen (onder andere een naald of een wattenstaafje) noodzakelijk. Daarnaast zijn - als throughput - apparatuur en personeel nodig om het lichaamsmateriaal te vervoeren en de analyse te verrichten. Als output komt uit de inzet van de DNA-vergelijking een rapport waarin staat of en in welke mate het onderzochte profiel overeenkomt met een profiel dat is opgenomen in de database. Als de input, throughput en output bekend zijn, kan de efficiëntie van een opsporingsmethode worden berekend. De berekening van de effectiviteit van het proces begint bij het resultaat (output). De effectiviteit van een proces (in dit geval het inzetten van de DNA-vergelijking als opsporingsmethode) hangt af van de vraag of het doel (waarheidsvinding) wordt bereikt. Als het resultaat van de methode een bijdrage levert aan het doel, dan is de methode (in bepaalde mate) effectief. Dit is de outcome van de bevoegdheid. De impact van de methode ziet op neveneffecten die worden bereikt door de

26 Taverne e.a. 2012.

27 Zie ook R.M. Kouwenhoven, R.J. Morée \& P. van Beers, Interventies in de opsporing. Impulsen in kwaliteit en effectiviteit van het opsporingsproces, Amsterdam/Apeldoorn: Reed Business/Politie \& Wetenschap 2013. De auteurs onderzoeken de stijging van de effectiviteit in de opsporing na implementatie van drie maatregelen (niet zijnde opsporingsmethoden): verbeteren van het aangifteproces, verbeteren van screenen en prioriteren en verhogen van de capaciteit.

28 B.P.A. van Mil, A.E. Dijkzeul \& M. Noordink, 'Beoordeling effectiviteit "Nieuwe Stijl”', Tijdschrift voor Toezicht 2012, 2, p. 82.

29 P.M. Wright \& G.C. McMahan, 'Theoretical perspectives for strategic human resource management', JOM 1992, 2, p. 295-320, met name p. 306; I. Proeller, 'Outcome-orientation in performance contracts: empirical evidence from Swiss local governments', IRAS 2007, 1, p. 95-111, met name p. 97; C. Pollit \& G. Bouckaert, Public management reform: a comparative analysis, Oxford: Oxford University Press 2011, p. 16; Taverne e.a. 2012, p. 50; Van Mil e.a. 2012, p. 82. 
methode te gebruiken. Zo kan worden gedacht aan het toenemen van het veiligheidsgevoel onder burgers, aan het toenemen van het vertrouwen in de strafrechtspleging als een nieuwe opsporingsmethode wordt gecreëerd of aan een generaal preventieve werking doordat de samenleving weet dat beter kan worden opgespoord. ${ }^{30}$

Voordat een opsporingsmethode kan worden gebruikt, dient te worden vastgesteld hoe effectief de methode is. De vraag naar de effectiviteit van een opsporingsbevoegdheid gaat over de invloed van de methode op de doelen van de strafrechtspleging. Een opsporingsmethode is doeltreffend als de toepassing ervan een bijdrage levert aan de waarheidsvinding. Om te voorkomen dat er fouten worden gemaakt - het onjuist uitsluiten van daderschap (een vals-negatieve fout) of onjuist aannemen van daderschap (een vals-positieve fout) - dient de informatie die door opsporingsbevoegdheden wordt verkregen betrouwbaar en conform de werkelijkheid te zijn. Een opsporingsmethode is derhalve effectiever naarmate de bevoegdheid met een grotere mate van zekerheid bijdraagt aan de waarheidsvinding.

Binnen het onderdeel outcome zijn mijns inziens de validiteit en betrouwbaarheid van de methode essentiële aandachtspunten om een opsporingsbevoegdheid op haar effectiviteit te toetsen. Validiteit houdt in dat de methode meet wat zij behoort te meten. Betrouwbaarheid betekent dat de gevonden resultaten representatief zijn voor de werkelijkheid. Alleen als een opsporingsbevoegdheid in voldoende mate betrouwbaar en valide is, wordt met een bepaalde mate van zekerheid de waarheid vastgesteld. Anders zijn de kansen te groot dat vals-negatieve of vals-positieve informatie de beslissingen van de officier van justitie of de rechter beïnvloedt. Dus hoe hoger de validiteit en betrouwbaarheid van een methode, hoe belangrijker de bijdrage aan de waarheidsvinding en hoe effectiever de methode is.

Naast de effectiviteit van een opsporingsmethode is de efficiëntie van de methode een belangrijke pijler om de bevoegdheid op te beoordelen. Justitie en politie beschikken immers over een beperkte opsporings- en vervolgingscapaciteit, terwijl zij wel de beschikking hebben over een grote verscheidend aan in te zetten opsporingsmethoden. Als de opsporende capaciteit beperkter is dan de omvang van de criminaliteit, is het efficiënt inzetten van opsporingsmethoden essentieel. Opsporingsmethoden die met minder kosten (ongeveer) hetzelfde resultaat behalen, hebben de voorkeur. De efficiëntie van een opsporingsbevoegdheid hangt af van de hoeveelheid middelen (input) en taken en processen (throughput) die noodzakelijk zijn om de resultaten van de methode (output) te verkrijgen. ${ }^{31}$

Er is echter zeer weinig informatie bekend over de efficiëntie van opsporingsmethoden. De kosten van de verschillende methoden die in Nederland worden ingezet, zijn niet inzichtelijk. Gegevens over in hoeveel strafzaken een bepaalde methode werd ingezet en in hoeveel zaken deze methode bewijs opleverde dat werd gebruikt voor een bewezenverklaring, worden niet gepubliceerd. Het is echter niet mogelijk om een efficiëntieberekening van verschillende opsporingsme- 
thoden te maken als de kosten en het aantal keer dat de methode bruikbaar, betrouwbaar bewijs heeft opgeleverd niet bekend zijn.

Uit bijvoorbeeld de behandeling van het DNA-verwantschapsonderzoek blijkt dat de regering efficiëntie niet als een belangrijke toets ziet bij de invoering van opsporingsmethoden. ${ }^{32}$ De toenmalige minister van Justitie Hirsch Ballin verwijst enkel naar positieve ervaringen met DNA-verwantschapsonderzoek in Engeland. In Engeland zou 33 keer in de database op familieverbanden zijn gezocht, waarvan destijds (2005) in zeven zaken een veroordeling was uitgesproken en vijf zaken onder de rechter waren. Als bekend is in hoeveel zaken een DNA-match met verwantschapsonderzoek is gevonden en hoe vaak de resultaten uit het DNAonderzoek als bewijs zijn gebruikt, kan een efficiëntieberekening worden gemaakt. Dit wordt echter nagelaten door de Nederlandse regering bij de introductie van het DNA-verwantschapsonderzoek. Het beleid lijkt neer te komen op wat Goldstein 'the means over ends syndrome' heeft gedoopt: als methoden beschikbaar zijn en resultaat kunnen opleveren, worden ze gecreëerd voor en gebruikt door de politie, ongeacht of de methode efficiënt is. ${ }^{33}$

De afwezigheid van efficiëntieberekeningen in het debat over de introductie van verschillende opsporingsmethoden en na enkele jaren praktijkervaring met de methoden betekent echter niet dat efficiëntie geen belangrijke pijler van opsporingsmethoden is of zou moeten zijn. Heijsman gebruikt de maatschappelijke energiebehoefte als metafoor om het belang van de financiële subsidiariteit duidelijk te maken: 'Om in onze toenemende energiebehoefte te kunnen voorzien, is de vraag naar olie zeer sterk toegenomen. Dit heeft geleid tot een enorme exploratie en exploitatie van oliebronnen. (...) Om in de energievraag van de toekomst te kunnen voorzien, is andere brandstof noodzakelijk: zoeken dus naar alternatieve energiebronnen. ${ }^{34}$ Ook in de opsporing moet volgens hem worden gezocht naar alternatieve mogelijkheden. De hoeveelheid criminaliteit overstijgt de opsporingscapaciteit. Efficiëntere inzet van middelen is derhalve noodzakelijk. En hier is meer en gedegen onderzoek voor nodig. En dat is broodnodig, gezien het volgende citaat: 'Strategische beslissers binnen het OM en de politie zijn immers, net als andere overheidsinstellingen, verplicht om ingezette capaciteit en middelen te verantwoorden en indien nodig bij te stellen. Deze bedrijfsmatige benadering van publiek bestuur wordt ook wel het new public management genoemd, waarin het liefst wordt gestuurd op "harde cijfers". 35

32 Kamerstukken II 2007/08, 31415, 1, p. 21.

33 H. Goldstein, 'Improving policing: a problem-oriented approach', Crime \& Delinquency 1979, 25, p. 238.

34 S. Heijsman, 'Toekomst van de opsporing: ontwikkelingen en scenario's', in: N. Kop \& P. Tops (red.), Toestand en toekomst van de opsporing, Apeldoorn: Politieacademie 2010, p. 29.

35 P. Duijn, 'Stilstaan of meebewegen? Over de effectiviteit van het opsporingsproces binnen de politie, belicht vanuit de bestrijding van georganiseerde hennepteelt', PROCES 2013/3, p. 178. 


\section{Conclusie}

De bewaarplicht voor telecommunicatiegegevens is zowel door het Europese Hof als de Rechtbank Den Haag in strijd met het recht op respect voor privacy geoordeeld. Politie en OM hebben getracht om in een rapport het belang van de bewaarplicht duidelijk te maken. Zonder efficiëntie- en effectiviteitsbeoordeling van de opsporingsmethode om telecommunicatiegegevens op te vragen en te analyseren, is het echter niet goed mogelijk het belang voor de opsporing van dit middel inzichtelijk te maken. Om de bewaarplicht te 'redden', maar ook om het belang voor de opsporing van het al bestaande arsenaal en nieuwe opsporingsmethoden te beoordelen, is om verschillende redenen een gedegen analyse noodzakelijk. Ten eerste stelt het steeds groeiende scala aan methoden de opsporingsautoriteiten voor een onwenselijke uitdaging. Zij moeten keuzes maken wat betreft in te zetten methoden uit de pool van alle methoden. Uit criminologisch onderzoek blijkt namelijk dat de politie regelmatig leidt aan the means over ends syndrome: als een methode beschikbaar is, wordt zij gecreëerd voor en gebruikt door de politie, ongeacht of de methode efficiënt is. (Te) weinig informatie over de effectiviteit en efficiëntie (en afwezigheid van voldoende tijd om een beslissing te nemen) kan ook leiden tot 'waan-van-de-dag-denken'. ${ }^{36}$ Ten derde wordt het nemen van beslissingen moeilijker naarmate er meer alternatieven zijn, zelfs tot het niveau dat 'beslissingsverlamming' ontstaat (de zogenoemde analysis paralysis): 'Decision sciences have been identifying decision heuristics that cut through the messy, confusing, overwhelming chaos of the real world so that we can avoid analysis paralysis and take action. ${ }^{37}$ Een van de heuristieken die dan invloed uitoefenen op het beslisproces is de confirmation bias, ${ }^{38}$ de neiging om naar bevestigend bewijs te zoeken en ontlastend bewijs te negeren. Van alle door Kahneman en Tversky ${ }^{39}$ beschreven heuristieken is de confirmation bias het meest schadelijk voor de waarheidsvinding, omdat daardoor mogelijk onschuldigen worden veroordeeld en schuldigen genegeerd. Ten vierde kan volgens Kop ineffectieve opsporing de legitimiteit en geloofwaardigheid van de politie aantasten. ${ }^{40}$ Een lage pakkans bij bepaalde delicten, aangiftes die op de plank blijven liggen en het

37 M.Q. Patton, 'What brain sciences reveal about integrating theory and practice', American Journal of Evaluation 2014, 2, p. 239.

38 Zie over tunnelvisie of, zoals zij het omschrijft, framing, het op 13 mei verschenen proefschrift van Renze Salet: R. Salet, Opsporing, tegenspraak en veranderende frames. Een onderzoek naar tegenspraak in grootschalige rechercheonderzoeken (diss. Nijmegen), Den Haag: Boom Lemma uitgevers 2015.

39 A. Tversky \& D. Kahneman, 'Judgment under uncertainty. Biases in judgments reveal some heuristics of thinking under uncertainty’, Science 1974, 4157, p. 1124-1131; D. Kahneman \& A. Tversky, 'Choices, values and frames', American Psychologist 1984, 4, p. 341-350; D. Kahneman \& A. Tversky (red.), Choices, values, and frames, Boston, MA: Cambridge University Press 2000; D. Kahneman, Thinking, fast and slow, Londen: Allen Lane 2011.

40 N. Kop, Van opsporing naar criminaliteitsbeheersing (oratie Politieacademie), Den Haag: Boom Lemma uitgevers 2012, p. 15. 
feit dat criminele organisaties ongestraft te werk kunnen gaan, ${ }^{41}$ worden door haar als voorbeelden van ineffectieve opsporing genoemd. Zowel vanuit rechtsbeschermend als instrumenteel perspectief is het daarom belangrijk de bruikbaarheid van beschikbare methoden goed te onderzoeken en eventueel te beperken.

41 Vgl. Duijn 2013. Hij benadrukt daarin dat de opsporing naar criminele organisaties in de hennepteelt inmiddels bestendig is tegen de traditionele projectmatige opsporingsonderzoeken. 'Nieuwe inzichten uit de wetenschap, nieuwe analysemethoden en de toegenomen beschikbaarheid aan informatie met betrekking tot het functioneren van criminele netwerken (zoals social media) nopen echter tot herziening van dit verouderde paradigma.' 